\title{
Pengaruh Penerapan Model Pembelajaran Inquiry Training Terhadap Hasil Belajar Siswa Pada Materi Pokok Listrik Dinamis Kelas IX Semester I SMP Swasta Sabilina Tembung
}

\author{
Khairul Amdani dan Achmad Suriyadi \\ Amdani.khairul@gmail.com \\ Jurusan Fisika FMIPA Universitas Negeri Medan \\ Jalan Willem Iskandar Pasar V Medan, 20221
}

\begin{abstract}
ABSTRAK
Penelitian ini bertujuan untuk mengetahui pengaruh model pembelajaran inquiry training terhadap hasil belajar siswa kelas IX SMP Swasta Sabilina Tembung pada materi pokok listrik dinamis. Jenis penelitian ini adalah quasi eksperimen dengan desain two group pre-test dan post-test. Populasi dalam penelitian adalah seluruh siswa kelas IX yang terdiri dari 11 kelas. Pengambilan sampel dilakukan dengan teknik cluster random sampling. Sampel penelitian terdiri dari dua kelas, satu kelas sebagai kelas eksperimen menggunakan model pembelajaran inquiry training dan satu kelas yang lain sebagai kelas kontrol menggunakan pembelajaran konvensional. Nilai rata-rata pretes kelas eksperimen dalah 51,6 dan nilai rata-rata pretes kelas kontrol 49,2. Setelah perlakuan diberikan, diperoleh hasil belajar siswa (postes) dengan nilai rata-rata 83,0 pada kelas eksperimen dan 77,8 pada kelas kontrol. Berdasarkan hasil uji t diperoleh bahwa ada pengaruh model pembelajaran inquiry training terhadap hasil belajar siswa pada materi pokok listrik dinamis di kelas IX semester I SMP Swasta Sabilina Tembung. Rerata aktivitas siswa pada kelas eksperimen adalah 81,9 (kategori sangat aktif) dan pada kelas kontrol adalah 60,4 (kategori aktif).
\end{abstract}

\section{Kata Kunci $\quad$ : Inquiry Training, Listrik Dinamis, Aktivitas Siswa}

\section{PENDAHULUAN}

Pada era globalisasi dan teknologi informasi seperti sekarang, adalah fakta yang tak dapat dipungkiri bahwa perubahanperubahan telah terjadi dengan sangat cepat, dramatis dan kompetitif dalam berbagai bidang kehidupan. Orang lain telah sangat jauh di depan dalam mengembangkan industri baru yang berbasis kompetensi sains dan teknologi tingkat tinggi. Saat ini orang yang dapat berhasil dan sukses hanyalah orang-orang yang berpendidikan dengan standar mutu tinggi dan berwawasan global.

Di sisi lain, hasil studi internasional tentang prestasi matematika dan sains siswa sekolah lanjutan tingkat pertama yang dilakukan TIMSS (Trend in International Mathematics and Science Study) pada tahun 2007, menun-jukkan bahwa kemampuan sains siswa Indonesia hanya menempati peringkat 35 dari 49 negara peserta. Hasil studi 
menyatakan bahwa rata-rata skor siswa kelas VIII Indonesia untuk pelajaran sains adalah 427 dan berada di bawah skor rata-rata internasional yang mencapai 500 . Hasil ini menunjukkan bahwa kemampuan siswa Indonesia di kancah global masih rendah dan perlu mendapat perhatian.

Berdasarkan hasil observasi peneliti di SMP Swasta Sabilina Tembung, terdapat beberapa permasalahan tentang pembelajaran fisika yang ditemukan bahwa masih banyak siswa yang menganggap fisika sebagai mata pelajaran yang sulit. Pada saat kegiatan belajar mengajar berlangsung, hanya sebagian siswa saja yang aktif. Ketika guru meminta siswa untuk bertanya tentang materi yang sedang dipe-lajari, tidak ada satupun siswa yang bertanya. Sama halnya ketika guru bertanya kepada siswa apakah materi yang disampaikan bisa dimengerti, siswa hanya diam saja dengan kata lain tidak ada siswa yang memberikan jawaban yang pasti. Berdasarkan wawancara dengan salah seorang Guru IPA di sekolah tersebut diketahui bahwa pembelajaran di kelas masih menggunakan cara belajar konvensional, siswa hanya dibelajarkan dengan metode ceramah, penugasan dan tanyajawab (pembelajaran masih berpusat pada guru), serta kurang mendorong siswa untuk berpikir kritis dan berpartisipasi aktif dalam proses belajar mengajar. Hal-hal ini menyebabkan nilai rata-rata hasil belajar siswa menjadi rendah, masih berada di bawah Ketuntasan Kompetensi Minimal (KKM). Ketuntasan Kompetensi Minimal untuk mata pelajaran fisika kelas IX di sekolah tersebut adalah 68. Bila keadaan ini dibiarkan terus berlanjut, dikhawatirkan tujuan pembelajaran nasional tidak akan tercapai.

Fisika (salah satu bidang sains) merupakan mata pelajaran yang mengharuskan siswa memahami, mengerti serta mengaplikasikannya dalam kehidupan nyata. Proses pembelajaran fisika menghendaki siswa aktif dalam proses berpikir dan mencari pemahaman akan objek, menganalisis dan mengkonstruksi pengetahuan tersebut sehingga terbentuk pengetahuan baru dalam individu. Salah satu upaya yang dapat dilakukan untuk mengatasi masalah tersebut di atas adalah melakukan pembelajaran dengan menerapkan model pembelajaran inquiry training (model latihan penelitian).

\section{Model Pembelajaran Inquiry \\ Training}

Model pembelajaran inquiry training dikembangkan oleh Suchman. Model pembelajaran ini didasarkan pada teori Suchman (Joyce, et al., 2009:203) yang menyatakan bahwa:

1. Secara alami siswa akan mencari sesuatu apabila dihadapkan pada masalah,

2. Mereka akan menjadi sadar tentang dan belajar mengenai strategi berpikir yang dimilikinya,

3. Strategi baru dapat diajarkan secara langsung melengkapi strategi yang telah dimiliki, dan

4. Penelitian yang bersifat kerjasama akan memperkaya proses berpikir dan membantu para mahasiswa untuk belajar tentang sifat tentatif dari pengetahuan, sifat selalu berkembang dari pengetahuan, 
dan menghargai berbagai alternatif penjelasan mengenai sesuatu hal.

Inkuiri adalah belajar mencari dan menemukan sendiri. Model pembelajaran inquiry training dirancang untuk mengajak siswa secara langsung ke dalam proses ilmiah melalui latihan-latihan meringkaskan proses ilmiah ke dalam waktu yang relatif singkat. Pembelajaran inkuiri memberi kesempatan kepada siswa untuk bereksplorasi dengan baik. Pembelajaran dengan metode inquiry memiliki 5 komponen yang umum yaitu:

1. Question (pembelajaran biasanya dimulai dengan sebuah pertanyaan pembuka yang memancing rasa ingin tahu siswa dan atau kekaguman siswa akan suatu fenomena).

2. Student

Engangement (keterlibatan aktif siswa merupakan suatu keharusan sedangkan peran guru adalah sebagai fasilitator).

3. Cooperative Interaction (siswa diminta untuk berkomunikasi, bekerja berpasangan atau dalam kelompok, dan mendiskusikan berbagai gagasan).

4. Performance Evaluation (dalam menjawab permasalahan siswa diminta untuk membuat sebuah produk yang dapat menggambarkan pengetahuannya mengenai permasalahan yang sedang dipecahkan).

5. Variety of Resources (siswa dapat menggunakan bermacam-macam sumber belajar).
Langkah-langkah Model Pembelajaran Inquiry Training

Model pembelajaran inquiry training memiliki lima langkah pokok (Joyce, at al., 2009:215) yakni:

1. Menghadapkan masalah: menjelaskan prosedur penelitian, menyajikan situasi yang saling bertentangan.

2. Menemukan masalah memeriksa hakikat objek dan kondisi yang dihadapi, memeriksa tampilnya masalah.

3. Mengkaji data dan eksperimentasi: mengisolasi variabel yang sesuai, merumuskan hipotesis.

4. Mengorganisasikan, merumuskan dan menjelaskan.

5. Menganalisis proses penelitian untuk memperoleh prosedur yang lebih efektif.

Model pembelajaran inquiry training adalah penting untuk mengembangkan nilai dan sikap serta cara berpikir ilmiah siswa, seperti: (1) keterampilan melakukan pengamatan, pengumpulan dan pengorganisasian data, termasuk merumuskan dan menguji hipotesis serta menjelaskan fenomena, (2) kemandirian belajar, keterampilan mengekspresikan secara verbal (4) kemampuan berpikir logis dan (5) kesadaran bahwa ilmu bersifat dinamis dan tentatif.

Tujuan utama dari model model pembelajaran ini adalah membuat siswa menjalani suatu proses tentang bagaimana pengetahuan diciptakan. Untuk mencapai tujuan ini, siswa dihadapkan pada suatu masalah yang misterius, belum diketahui tetapi menarik. Namun perlu diingat bahwa masalah tersebut harus didasarkan pada 
suatu gagasan yang memang dapat ditemukan (discoverable ideas), bukan mengada-ada.

Tidak cukup hanya sekedar ceramah dalam upaya menanamkan konsep kepada siswa, misalnya konsep IPA fisika pokok bahasan Listrik Dinamis. Pembelajaran akan lebih bermakna jika siswa diberi kesempatan untuk tahu dan terlibat secara aktif dalam menemukan konsep dari fakta-fakta yang dilihat dari lingkungan dengan bimbingan guru.

Model latihan penelitian (inquiry training) dapat dirancang dengan baik, jika guru yang mengontrol interaksi dan meresapkan prosedurprosedur penyelidikan. Meski demikian, standar penyelidikannya adalah kerja sama, kebebasan intelektual, dan keseimbangan. Interaksi antara siswa seharusnya juga didorong. Lingkung-an intelektual terbuka untuk semua gagasan yang relevan, guru dan siswa seharusnya berpartisipasi secara sejajar di mama gagasangagasan bisa saling terhubung satu sama lain.

Model pembelajaran ini memerlukan dukungan yang optimal, yakni seperangkat bahan/materi yang mengkonfrontasi, seorang guru yang memahami proses intelektual dan strategi penelitian, dan materi-materi sumber yang menopang suatu penjelasan.

Prinsip pengelolaan/rekasi dari model ini meliputi: (1) Pertanyaan yang diajukan harus diungkapkan dengan baik sehingga pertanyaan tersebut dapat dijawab dengan "ya" atau "tidak" dan substansi pertanyaannya tidak mengharuskan guru melakukan penyelidikan. (2) Meminta siswa untuk mengutarakan kembali pertanyaan yang kurang baik. (3) Menegaskan/menunjukkan poin-poin yang tidak disahkan, misalnya, "Kami tidak menegaskan bahwa ini adalah cairan". (4) Menggunakan bahasa proses penelitian, misalnya mengidentifikasi pertanyaanpertanyaan siswa sebagai teori dan mengajak siswa melakukan pengujian (bereksperimen).

Mencoba menyediakan lingkungan intelektual yang bebas dengan cara tidak menilai teori-teori yang diajukan siswa dengan keras. (6) Mendesak siswa untuk membuat pernyataan-pernyataan teori yang lebih jelas dan selanjutnya memberikan dukungan dalam menggeneralisasi teori itu. (7) Memberikan dorongan dan kemudahan bagi para siswa untuk melakukan interaksi diantara mereka.

Dampak instruksional model inquiry training ini adalah: (1) Strategi-strategi penelitian kreatif. (2) Proses-proses ilmiah. Dampak pengiring dari model meliputi: (1) Spirit kreativitas, (2) Kemandirian dan otonomi dalam pembelajaran. (3) Toleran pada ambiguitas. (4) Sifat pengetahuan yang tentatif.

\section{METODE PENELITIAN}

Penelitian ini dilaksanakan di SMP Swasta Sabilina Tembung yang beralamat di jalan Beringin Tembung Kabupaten Deli Serdang. Populasi dalam penelitian ini adalah seluruh siswa kelas IX semester I SMP Swasta Tembung yang terdiri dari 11 kelas. Sampel dalam penelitian terdiri dari dua kelas yaitu kelas eksperimen dan kelas kontrol yang diambil dengan teknik cluster random sampling. Kelas pertama sebagai kelas eksperimen, 
menggunakan model pembelajaran inquiry training dan kelas kedua sebagai kelas kontrol, menggunakan pembelajaran konvensional (yang biasa dilaksanakan dalam pembelajaran sehari-hari). Untuk mengetahui hasil belajar siswa, dilakukan dengan memberikan tes pada kedua kelas sebelum dan sesudah diberi perlakuan. Rancangan penelitian ini ditunjukkan pada Tabel 1.

Tabel 1 Pretest-Postest Design

\begin{tabular}{|c|c|c|c|}
\hline Kelas & $\begin{array}{c}\text { Tes } \\
\text { Awal }\end{array}$ & Perlakuan & $\begin{array}{c}\text { Tes } \\
\text { Akhir }\end{array}$ \\
\hline Eksperimen & $\mathrm{T}_{1}$ & $\mathrm{X}_{1}$ & $\mathrm{~T}_{2}$ \\
\hline Kontrol & $\mathrm{T}_{1}$ & $\mathrm{X}_{2}$ & $\mathrm{~T}_{2}$ \\
\hline
\end{tabular}

Keterangan :

$\mathrm{X}_{1}=$ Pembelajaran dengan model inquiry training

$\mathrm{X}_{2}=$ Pembelajaran konvensional $\mathrm{T}_{1}=$ Pemberian tes awal (pretest) $\mathrm{T}_{2}=$ Pemberian tes akhir (postest)

Uji Lilliefors digunakan untuk mengetahui apakah data kedua sampel berdistribusi normal. Uji homogenitas digunakan untuk mengetahui apakah kedua sampel berasal dari populasi yang homogen. Uji homogenitas menggunakan uji kesamaan varians.

Untuk menguji hipotesis apakah hasil belajar siswa yang dibelajarkan dengan menggunakan model pembelajaran inquiry training secara signifikan lebih tinggi dibandingkan dengan hasil belajar siswa yang dibelajarkan dengan pembelajaran konvensional, kebenarannya dapat diterima atau ditolak, maka digunakan uji beda atau uji t dengan rumus

$$
t=\frac{\bar{x}_{1}-\bar{x}_{2}}{s \sqrt{\frac{1}{n_{1}}+\frac{1}{n_{2}}}}
$$

$S$ adalah varians gabungan yang dihitung dengan rumus

dengan

$$
S^{2}=\frac{\left(n_{1}-1\right) S_{1}^{2}+\left(n_{2}-1\right) S_{2}^{2}}{n_{1}+n_{2}-2}
$$

$$
t=\text { distribusi } t
$$

$\bar{x}_{1}=$ Nilai rata-rata kelas eksperimen

$\bar{x}_{2}=$ Nilai rata-rata kelas kontrol

$n_{1}=$ Ukuran kelas eksperimen

$n_{2}=$ Ukuran kelas kontrol

$S_{1}^{2}=$ Varians kelas eksperimen

$S_{2}^{2}=$ Varians kelas kontrol

Taraf signifikan (a) yang digunakanan $=0,05$ dengan kriteria pengujian jika thitung $>t_{\text {tabel }}$ pada $\mathrm{dk}$ $=\mathrm{n}_{1}+\mathrm{n}_{2}-2$, maka Ha diterima.

\section{HASIL PENELITIAN DAN PEMBAHASAN}

\section{a. Hasil Penelitian}

Awal penelitian, kedua kelas diberikan tes uji kemampuan awal (pretes) yang bertujuan untuk mengetahui apakah kemampuan awal siswa pada kedua kelas sama atau tidak. Berdasarkan data hasil penelitian diperoleh nilai rata-rata pretes siswa pada kelas eksperimen sebelum diberi perlakuan dengan menggunakan model pembelajaran inquiry training adalah 51,6 dengan standar deviasi 9,2. Sedangkan pada kelas kontrol, diperoleh nilai ratarata pretes siswa sebesar 49,2 dengan standar deviasi 10,7. 


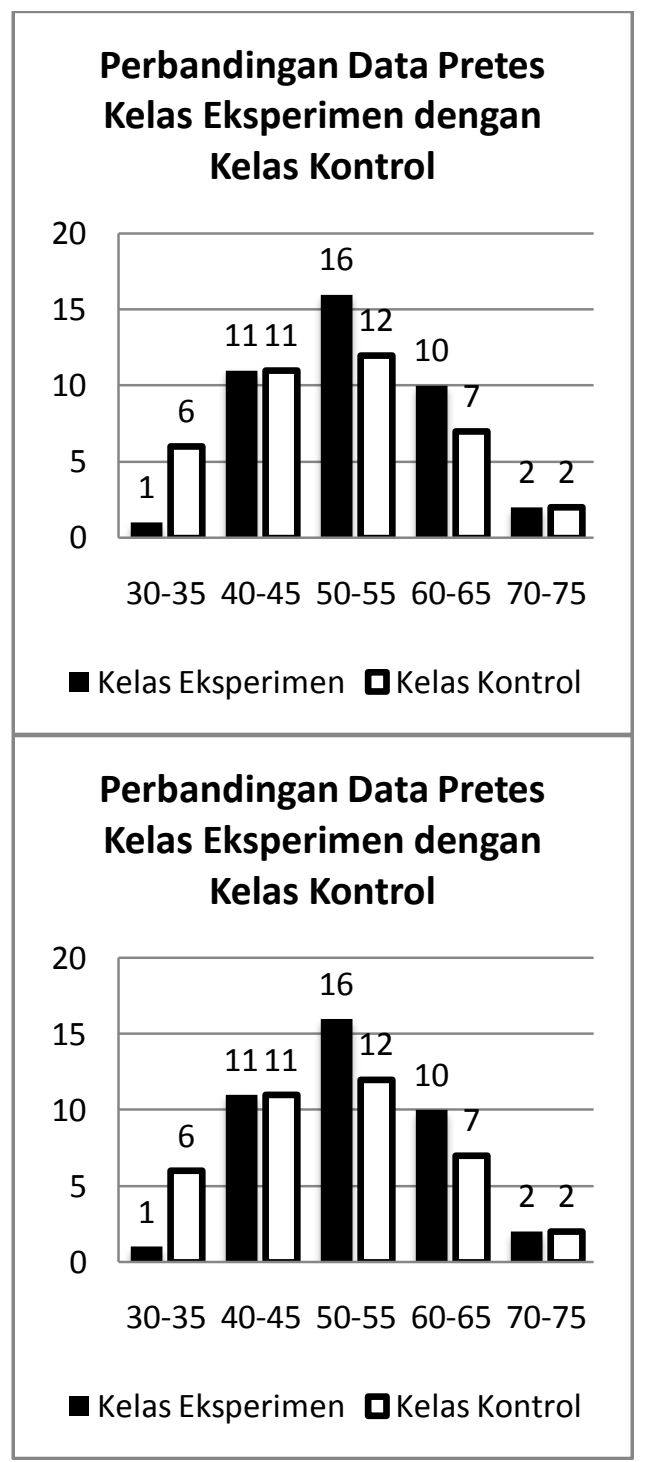

Gambar 1 Diagram batang data pretes kelas eksperimen dan kontrol

Sebelum dilakukan uji hipotesis, terlebih dahulu dilakukan uji prasyarat data yaitu uji normalitas menggunakan uji Lilliefors. Dari uji normalitas diperoleh hasil, untuk kelas eksperimen $L_{\text {hitung }}=0,0675$ dan untuk kelas kontrol $L_{\text {hitung }}=$ 0,1036. $L_{\text {tabel }}=0,1384$. Kesim- $^{-}$ pulannya, kedua kelas berdistribusi normal.

Pengujian homogenitas dilakukan untuk mengetahui apakah kelas sampel berasal dari populasi yang homogen atau tidak, artinya apakah sampel yang digunakan dalam penelitian ini dapat mewakili seluruh populasi yang ada. Pengujian homogenitas data dilakukan dengan uji $F$. Dari uji homogenitas data diperoleh hasil, $F_{\text {hitung }}<F_{\text {tabel }}=1,35<1,72$. Kesimpulannya, kedua sampel berasal dari populasi yang homogen.

Setelah diketahui bahwa data pretes kedua kelas normal dan homogen, maka pada kedua kelas sampel diberikan perlakuan yang berbeda. Pada kelas eksperimen diberikan perlakuan dengan menerapkan model pembelajaran inquiry training dan pada kelas kontrol diberikan perlakuan dengan menerapkan konvensional.

Setelah kedua kelas diberikan perlakuan yang berbeda, kedua kelas selanjutnya diberikan postes dengan soal soal yang sama seperti soal pretes. Hasil yang diperoleh adalah, nilai rata-rata postes kelas ekspe-rimen setelah diterapkan model pembelajaran inquiry training $=83,0$ dengan standar deviasi 7,6. Pada kelas kontrol, diperoleh nilai rata-rata postes 77,8 dengan standar deviasi 9,1. Data postes kelas eksperimen dan kontrol ditunjukkan pada Gambar 2.

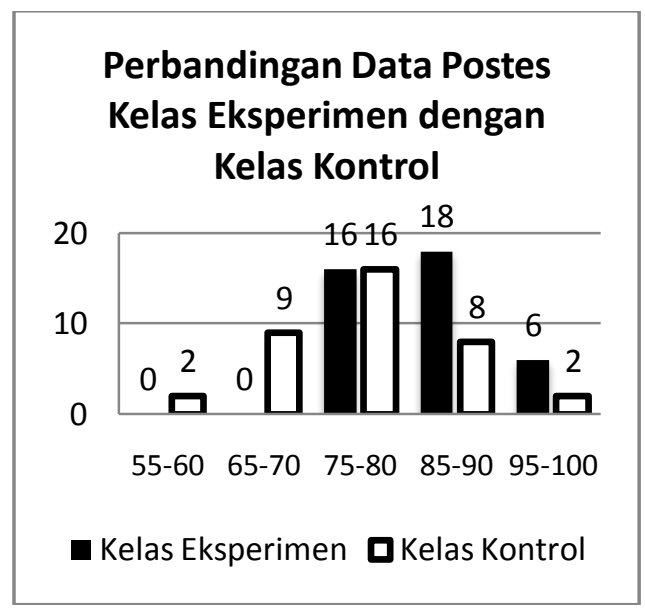

Gambar 2 Diagram batang data postes kelas eksperimen dan kontrol 
Berdasarkan hasil uji hipotesis diperoleh $t_{\text {hitung }}>t_{\text {tabel }}=2,42>1,66$, artinya ada perbedaan akibat pengaruh menggunakan model pembelajaran inquiry training terhadap hasil belajar siswa kelas IX SMP Swasta Sabilina Tembung pada materi pokok listrik dinamis.

Hasil observasi aktivitas belajar siswa selama menerapkan model pembelajaran inquiry training memiliki rata-rata skor aktivitas siswa pada ketiga pertemuan sebesar 81,9 (kategori sangat aktif). Pada kelas kontrol (yang dibelajarkan dengan menerapkan cara belajar konvensional), memiliki rata-rata skor aktivitas siswa pada ketiga pertemuan sebesar 60,4 (kategori aktif).

\section{b. Pembahasan}

Penelitian ini dilakukan di kelas IX pada dua kelas dengan perlakuan yang berbeda, kelas kontrol dengan pembelajaran konvensional dan kelas eksperimen dengan dengan model pembelajaran inquiry training. Pada awal penelitian masing-masing kelas diberikan pretes untuk mengetahui kemampuan awal siswa. Dari hasil pretes diperoleh hasil belajar siswa pada kelas kontrol, rata-rata 49,2 dan pada kelas eksperimen, ratarata 51,6. Dari uji normalitas dan homogenitas menunjukkan bahwa data pretes kedua kelas berdistribusi normal dan berasal dari populasi yang homogen.

Berdasarkan hasil postes terlihat bahwa nilai rata-rata hasil belajar kelas eksperimen setelah dibelajarkan dengan model pembelajaran inquiry training lebih tinggi dari pada nilai rata-rata hasil belajar kelas kontrol yang dibelajarkan dengan cara pembelajaran konvensional (83,0 untuk kelas eksperimen dan 77,8 untuk kelas kontrol). Hasil uji hipotesis menunjukkan bahwa thitung $>t_{\text {tabel }}(2,42>1,66)$, sehingga dapat diartikan bahwa ada perbedaan akibat pengaruh penggunaan model pembelajaran inquiry training terhadap hasil belajar siswa kelas IX SMP Swasta Sabilina Tembung pada materi pokok listrik dinamis. Hal ini menunjukkan bahwa model pembelajaran inquiry training merupakan salah satu pembelajaran yang lebih unggul dari pembelajaran konven-sional. Model pembelajaran inquiry training memberi peluang yang sama kepada semua siswa, baik siswa yang memiliki kemampuan rendah, sedang ataupun tinggi untuk berhasil. Oleh karena itu, siswa yang berkemampuan rendah, sedang maupun tinggi semuanya ditantang untuk dapat menemukan materi melalui praktikum dengan bantuan bimbingan dari peneliti. Model pembelajaran inquiry training juga mendorong siswa lebih aktif dalam belajar, karena dengan model ini, pengetahuan dan keterampilan yang diperoleh oleh siswa bukan hanya hasil mengingat seperangkat faktafakta, tetapi juga merupakan hasil dari menemukan sendiri. Dengan model ini siswa dapat bekerja sama dan memberikan masukan-masukan pada siswa yang lain sehingga siswa yang kurang mampu menjadi lebih termotivasi untuk mempelajari materi yang kurang dimengerti.

Berdasarkan hasil observasi aktivitas belajar siswa juga terlihat ada peningkatan tiap pertemuan. Pada kelas eksperimen, aktivitas siswa dalam kegiatan pembelajaran lebih aktif dibandingkan dengan kelas kontrol. Selama kegiatan 
pembelajaran, tidak terlihat adanya siswa yang menunjukkan sikap acuh tak acuh, menentang, terlihat tidak suka terhadap materi yang diajarkan, tidur atau bermalasmalasan di kelas. Semua siswa aktif mengikuti pelajaran dan mengajukan pertanyaan sehingga KBM dapat berjalan dengan baik.

Meskipun hasil belajar dan aktivitas siswa meningkat, namun masih ada kendala yang dihadapi peneliti dalam melakukan penelitian ini, yakni, pertama, kurangnya kemampuan siswa membuat pertanyaan yang mengandung jawaban "ya" atau "tidak". Sebagai contoh, siswa masih bertanya tentang bagaimana cara membuat rangkaian percobaan yang benar, bagaimana menggunakan alat ukur (amperemeter), dan partanyaan lain yang sejenis. Kesulitan kedua adalah adanya siswa yang tidak serius dalam kelompok pada saat praktikum sehingga dapat mengganggu keseriusan anggota kelompok yang lain.

\section{KESIMPULAN}

Berdasakan hasil observasi aktivitas siswa di kelas eksperimen yang menggunakan model pembelajaran inquiry training diperoleh rata-rata aktivitas siswa sebesar 81,9 (kategori sangat aktif) dan rata-rata aktivitas siswa pada kelas kontrol sebesar 60.35 (kategori aktif).

Berdasarkan pengujian hipotesis menggunakan uji $t$ pada taraf signifikan $\alpha=0,05$ dan $\mathrm{dk}=76$ diperoleh $t_{\text {hitung }}=2,24$ dan $t_{\text {tabel }} 1,66$ ( $\left.t_{\text {hitung }}>t_{\text {tabel }}\right)$, sehingga dapat dinyatakan bahwa ada perbedaan yang signifikan akibat pengaruh model pembelajaran inquiry training terhadap hasil belajar siswa pada materi pokok listrik dinamis di kelas IX SMP Swasta Sabilina Tembung.

\section{DAFTAR PUSTAKA}

Arikunto, S., (2003), Manajemen Penelitian, Rineka Cipta, Jakarta.

Joyce, B., Weil, M. \& Calhoun, E. (2009), Models of Teaching, Edisi Delapan, Pustaka Pelajar, Yogyakarta

Uno, H. B., (2010,) Model Pembelajaran, Bumi Aksara, Jakarta.

Sanjaya, W., (2008), Strategi Pembelajaran Berorientasi Standar Proses Pendidikan, Kencana, Jakarta.

Sardiman, (2001), Interaksi dan Motivasi Belajar Mengajar, Raja Grafindo Persada, Jakarta.

Slameto, (2003), Belajar dan FaktorFaktor yang Mempengaruhinya, Rineka Cipta, Jakarta.

Sudjana, M. A., (2005), Metoda Statistika, Tarsito, Bandung.

Trianto,(2007), Model-model Pembelajaran Inovatif Berorientasi Konstruktivistik, Prestasi Pustaka, Jakarta.

TIMSS. 2007. Summary Report On The Achievement Of The 4th And 8th Grade Student In Mathematic And Science. (http://litbangkemdiknas.net/deta il.php?id=214).

Willis, Dahar, (1989), Teori-teori Belajar, Gelora Aksara Prima, Erlangga. 